\title{
EFFECT OF DIETARY PROTEIN AND ENERGY ON GROWTH OF JUVENILE HUMPBACK GROUPER (Cromileptes altivelis)
}

\author{
Nyoman Adiasmara Giri, Ketut Suwirya and Muhammad Marzuqi
}

\begin{abstract}
The effect of varying protein and energy contents of diet on the growth and nutrient retention of juvenile humpback grouper was examined using a $3 \times 3$ factorial design with three replicates. Ten fish of average body weight $( \pm S D$ ) of $4.7 \pm 0.5 \mathrm{~g}$ were stocked into each of 27 polycarbonate tanks $(30 \mathrm{~L})$ with a flow-through system. Nine experimental diets were prepared containing three dry matter (DM) protein levels of $44 \%, 50 \%$ and $56 \%$ and three DM lipid levels of $6 \%, 9 \%$ and $12 \%$. Calculated DM energy content of the diets ranged from 4.32 to $4.95 \mathrm{kcal} / \mathrm{g}$ diet; the protein and energy ratio ranged from 94.9 to $124.9 \mathrm{mg} / \mathrm{kcal}$. Chloroform-methanol extracted fish meal and squid liver meal were main protein sources, with small amounts of additional casein and mysid shrimp meal. Experimental diets were prepared as freeze-dried pellets. Fish were fed twice daily to satiation for 84 days. Final weight, percent weight gain (WG), survival, feed efficiency (FE), protein efficiency ratio (PER), as well as protein and lipid retention data were analyzed using twoway ANOVA. There was a significant interaction between the protein and lipid content of the diet only in final weight and WG, where fish performance improved with increasing protein content with the $9 \%$ lipid diet but not for either the $6 \%$ or $12 \%$ lipid diet. Total length, FE and lipid retention increased with increasing dietary protein content while lipid retention also increased with increasing dietary lipid. PER and protein retention were unaffected by the diet. These results indicated that a diet containing 56\% DM protein, 9\% DM lipid, $4.77 \mathrm{kcal} / \mathrm{g}$ diet, and protein: energy ratio of $118 \mathrm{mg} / \mathrm{kcal}$ was the best for growth of juvenile humpback grouper.
\end{abstract}

KEYWORDS: humpback grouper, protein, energy, growth, protein efficiency ratio

\section{INTRODUCTION}

Humpback grouper (Cromileptes altivelis) has a high market value, especially in Asian countries such as Hong Kong, Singapore and Taiwan. Grouper fish, predominantly Epinephelus spp. has been cultured throughout Asia for many years with commercial production based on captured wild seed being on-grown using trash fish as feed. Recently, hatchery technology for seed production of humpback grouper has been successfully developed (Sugama et al., 2001) and has stimulated interest in grow-out of this species. However, at present there is no formulated grow-out feed available commercially for humpback grouper and information on its nutritional requirement is very limited.

Some experiments on nutrient requirement for this species have been conducted to gain basic information for developing a formulated feed. Giri et al. (1999) reported that humpback grouper juveniles required $54.2 \%$ protein and $9 \%-10 \%$ lipid in the diet for good growth. Dietary protein requirement for some others species of grouper has been reported to vary from $47.8 \%$ to $60.0 \%$, e.g. Epinephelus salmoides, $50 \%$ (Teng et al., 1978); E. striatus, more than $55 \%$ (Ellis et al., 1996); E. akaara, 49.5\% (Chen et al., 1995); and E. malabaricus, $47.8 \%$ (Chen and Tsai, 1994). This information shows that groupers require a rela- tively high concentration of dietary protein for normal growth. This high dietary protein requirement, using a high level of fish meal as the protein source, becomes a new problem in feed formulation. Replacing fish meal with soybean meal has not given good results for growth of juvenile humpback grouper. Inclusion up to $10 \%$ soybean meal in the diet resulted in good growth of fish, but inclusion of $20 \%$ or more soybean meal significantly retarded growth of fish (Marzuqi et al., unpublished data).

Fish use dietary protein for growth and, importantly, also as a primary source of energy. In order to minimize the utilization of protein for energy, the diet should contain enough sources of energy other than protein. Thus, feed formulation should be based on the energy requirement of the fish and an optimum protein to energy ratio in order to optimize the utilization of protein for growth. The objective of the present study was to see if growth and chemical composition of juvenile humpback grouper are affected by the protein: energy ratio of the diet.

\section{MATERIAL AND METHODS}

\section{Experimental Diets}

Nine experimental diets varying factorially in dry matter (DM) protein $(44 \%, 50 \%$, and $56 \%)$ and DM

\footnotetext{
7) Researcher at Research Institute for Mariculture Gondol, Bali
} 
lipid (6\%, 9\%, and 12\%) were prepared. Diets were formulated using chloroform-methanol extracted fish meal and squid liver meal as major protein sources, with additional protein supplied by mysid shrimp meal and casein (Table 1). Dextrin was used to adjust the gross energy content of the diets. The protein: energy ratio of the diets ranged from 94.9 to 124.9 (mg/ $\mathrm{kcal})$ and decreased with increasing lipid concentration, regardless of the dietary protein content. Diets were prepared using an Hiraga meat chopper and cold extruded through a die with a hole diameter of 2.2 $\mathrm{mm}$. Pellets were freeze-dried and were kept in a refrigerator $\left(4^{\circ} \mathrm{C}\right)$ before and during feeding experiment.

\section{Feeding Trial}

Juvenile humpback grouper were produced in the hatchery at the Gondol Research Institute for Mariculture. These juveniles readily accepted the experi- mental diets as they had been offered dry food since day 17 old larvae and reared after metamorphosis entirely on fry food. A total of 270 selected juveniles with mean SD of $4.7 \pm 0.5 \mathrm{~g}$ body weight were randomly and equally assigned as three replicate blocks to 27 rounded polycarbonate tanks, each of $30 \mathrm{~L}$ volume. Each tank was supplied with flow-through sea water and an individual airstone to maintain good water quality throughout the 12-week experiment. Fish were fed twice daily to satiation.

Body weight, total length and survival were recorded every week. At the end of the experiment, a representative sample of fish from each tank were dried and the chemical composition of the fish were determined. Crude protein, lipid, and ash contents of diets and fish were analyzed following the standard methods of AOAC (1990). Energy content of the diet was calculated based on caloric coefficients of 5.64, 9.44 and

Table 1. Composition of the experimental diet (\% dry matter)

\begin{tabular}{|c|c|c|c|c|c|c|c|c|c|}
\hline \multirow{2}{*}{ Ingredient } & \multicolumn{9}{|c|}{ Diet No. } \\
\hline & 1 & 2 & 3 & 4 & 5 & 6 & 7 & 8 & 9 \\
\hline Casein & 1.40 & 1.40 & 1.40 & 7.67 & 7.67 & 7.67 & 13.97 & 13.97 & 13.97 \\
\hline Fish meal $^{1}$ & 45.00 & 45.00 & 45.00 & 48.00 & 48.00 & 48.00 & 50.00 & 50.00 & 50.00 \\
\hline Squid liver meal ${ }^{1}$ & 10.00 & 10.00 & 10.00 & 10.00 & 10.00 & 10.00 & 10.00 & 10.00 & 10.00 \\
\hline Mysid shrimp meal & 10.00 & 10.00 & 10.00 & 7.50 & 7.50 & 7.50 & 5.00 & 5.00 & 5.00 \\
\hline Dextrin & 16.68 & 16.68 & 16.68 & 11.47 & 11.47 & 11.47 & 5.91 & 5.91 & 5.91 \\
\hline Mineral mix ${ }^{2}$ & 1.70 & 1.70 & 1.70 & 1.70 & 1.70 & 1.70 & 1.70 & 1.70 & 1.70 \\
\hline Vitamin mix $^{3}$ & 1.30 & 1.30 & 1.30 & 1.30 & 1.30 & 1.30 & 1.30 & 1.30 & 1.30 \\
\hline Squid oil & 4.12 & 7.12 & 10.12 & 4.14 & 7.14 & 10.14 & 4.18 & 7.06 & 9.93 \\
\hline Astaxanthin & 0.19 & 0.19 & 0.19 & 0.19 & 0.19 & 0.19 & 0.19 & 0.19 & 0.19 \\
\hline CMC & 2.00 & 2.00 & 2.00 & 2.00 & 2.00 & 2.0 & 2.00 & 2.00 & 2.00 \\
\hline Cellulose & 7.61 & 4.61 & 1.61 & 6.03 & 3.03 & 0.03 & 5.75 & 2.87 & 0.00 \\
\hline \multicolumn{10}{|c|}{ Proximate composition (\% dry mt.) } \\
\hline Protein $(\%)$ & 44.3 & 44.8 & 44.3 & 50.0 & 50.1 & 50.8 & 56.2 & 56.3 & 55.4 \\
\hline Lipid (\%) & 7.3 & 8.8 & 12.6 & 6.8 & 9.5 & 12.3 & 6.0 & 9.9 & 12.4 \\
\hline Fiber $(\%)$ & 9.5 & 8.5 & 7.8 & 9.1 & 7.3 & 4.7 & 7.8 & 6.5 & 5.4 \\
\hline Ash (\%) & 11.4 & 11.3 & 11.5 & 11.5 & 11.5 & 11.4 & 11.4 & 11.2 & 10.9 \\
\hline NFE $(\%)$ & 27.5 & 26.6 & 23.8 & 22.6 & 21.6 & 20.8 & 18.6 & 16.1 & 15.9 \\
\hline Energy $(\mathrm{kcal} / \mathrm{g})^{4}$ & 4.3 & 4.5 & 4.7 & 4.4 & 4.6 & 4.9 & 4.5 & 4.8 & 5.0 \\
\hline $\begin{array}{l}\text { Protein/energy } \\
\text { ratio (mg/kcal) }\end{array}$ & 102.6 & 100.7 & 94.9 & 113.9 & 108.7 & 104.1 & 124.9 & 118.0 & 112.0 \\
\hline$E / P(\mathrm{kcal} / \mathrm{kg})$ & 97.5 & 99.3 & 105.3 & 87.8 & 92.0 & 96.1 & 80.1 & 84.8 & 89.3 \\
\hline \multicolumn{10}{|c|}{ 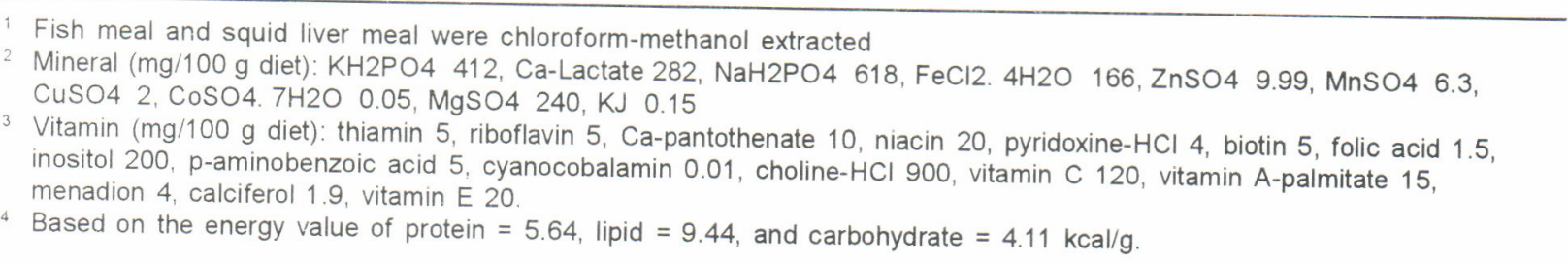 } \\
\hline
\end{tabular}


$4.11 \mathrm{kcal} / \mathrm{g}$ for protein, lipid, and carbohydrate, respectively (Jobling, 1983). Final weight, percent weight gain (WG), survival, feed efficiency (FE), protein efficiency ratio (PER) as well as protein and lipid retention data were analyzed using two-way ANOVA. If there was no interaction between main effects of dietary protein and lipid, means were compared using one-way ANOVA and differences between treatments were considered significant at $P<0.05$ (Steel and Torrie, 1980).

\section{RESULTS}

Proximate analysis of experimental diets showed that the protein and lipid contents of the diets closely agreed with expected values (Table 1). Energy content of the diets ranged from 4.32 to $4.95 \mathrm{kcal} / \mathrm{gram}$ and the protein: energy ratio ranged from 94.9 to 124.9 $\mathrm{mg} / \mathrm{kcal}$.

There was a significant interaction between the protein and lipid content of the diet for final weight and WG, wherein fish performance improved with increasing protein content for the $9 \%$ lipid diet, but not for either the $6 \%$ or $12 \%$ lipid diet (Table 2 ). The mean survival on each treatment exceeded $93 \%$ over the experimental period of 84 days and was unaffected by the protein or lipid content of the diet (Table 3). Total length, FE and lipid retention increased with in- creasing dietary protein content, while lipid retention also increased with increasing dietary lipid. PER and protein retention were unaffected by the diet (Table 3).

\section{Discussion}

Results of the study showed that increasing the DM concentration of protein in the diet from $44 \%$ to $56 \%$ increased the growth of fish. The best growth was gain with the diet containing $56 \%$ DM protein and $9 \%$ DM lipid. This dietary protein concentration closely agrees with that reported by Giri et al. (1999) who found growth of juvenile humpback grouper was maximal at $54.2 \%$ protein. For other species of grouper, the dietary protein requirement has variously been reported to lie between $47.8 \%$ and $60 \%$. This wide variation could be influenced by species, the nature of the feed ingredients used and differences in the supply of other nutrients in the experimental diets fed to the fish. Rachmansyah et al. (2000) reported that growth of juvenile humpback grouper fed diets containing from $48 \%$ to $54 \%$ protein was not significantly different and concluded that the dietary protein requirement was $48 \%$. In their experiment they used larger fish of $13.5 \mathrm{~g}$ to $15.1 \mathrm{~g}$ initial weight compared with $4.7 \mathrm{~g}$ fish used in the present study or $5.5 \mathrm{~g}$ fish as used in our earlier study (Giri et al., 1999).

Table 2. Final weight and body weight gain of fish fed experimental diets for 84 days $^{1}$

\begin{tabular}{ccccc}
\hline $\begin{array}{c}\text { Diet } \\
\text { no. }\end{array}$ & \multicolumn{2}{c}{ Dietary factor } & $\begin{array}{c}\text { Final weight } \\
(\mathbf{g})\end{array}$ & $\begin{array}{c}\text { Body weight gain } \\
(\%)\end{array}$ \\
\hline 1 & 44 & 6 & $25.68 \pm 1.35^{\mathrm{ab}}$ & $440.5 \pm 23.6^{\mathrm{ab}}$ \\
2 & 44 & 9 & $24.13 \pm 1.45^{\mathrm{a}}$ & $411.7 \pm 24.9^{\mathrm{a}}$ \\
3 & 44 & 12 & $25.22 \pm 0.75^{\mathrm{ab}}$ & $436.9 \pm 11.0^{\mathrm{ab}}$ \\
4 & 50 & 6 & $26.95 \pm 0.74^{\mathrm{bc}}$ & $474.4 \pm 47.3^{\mathrm{bc}}$ \\
5 & 50 & 9 & $25.33 \pm 0.97^{\mathrm{ab}}$ & $443.2 \pm 13.5^{\mathrm{ab}}$ \\
6 & 50 & 12 & $26.47 \pm 1.47^{\mathrm{b}}$ & $460.1 \pm 36.7^{\mathrm{b}}$ \\
7 & 56 & 6 & $27.82 \pm 1.43^{\mathrm{c}}$ & $477.0 \pm 32.5^{\mathrm{bc}}$ \\
8 & 56 & 9 & $28.92 \pm 1.60^{\mathrm{c}}$ & $527.8 \pm 28.7^{\mathrm{c}}$ \\
9 & 56 & 12 & $26.94 \pm 0.59^{\mathrm{bc}}$ & $469.9 \pm 10.7^{\mathrm{b}}$ \\
\hline
\end{tabular}

\begin{tabular}{lcc}
\hline ANOVA & & \\
Protein & 0.00002 & 0 \\
Lipid & $\mathrm{NS}^{3}$ & $\mathrm{NS}$ \\
Protein vs Lipid & 0.0046 & 0.0085 \\
\hline $\begin{array}{l}\text { Initial weight }=4.7 \pm 0.5 \mathrm{~g} \text {. Initial length }=6.9 \pm 0.3 \mathrm{~cm} . \text { Values in the column } \\
\text { followed by the same latter are not significantly different }(P>0.05) .\end{array}$ \\
2 Probability of significance \\
3 Non-significant $(P>0.05)$
\end{tabular}


Table 3. Survival, total length, feed efficiency, protein efficiency ratio, protein and lipid retention of fish fed experimental diets for 84 days $^{1}$

\begin{tabular}{cccccccc}
\hline $\begin{array}{c}\text { Dietary Dietary } \\
\text { factor } \\
\text { level }\end{array}$ & $\begin{array}{c}\text { Survival } \\
(\%)\end{array}$ & $\begin{array}{c}\text { Total length } \\
(\mathrm{cm})\end{array}$ & $\mathrm{FE}^{2}$ & $\mathrm{PER}^{3}$ & $\begin{array}{c}\text { Protein } \\
\text { retention }\end{array}$ & $\begin{array}{c}\text { Lipid } \\
\text { retention }\end{array}$ \\
\hline Protein & 44 & $98.9^{\mathrm{a}}$ & $12.04 \pm 0.09^{\mathrm{a}}$ & $0.64 \pm 0.03^{\mathrm{a}}$ & $1.66 \pm 0.07^{\mathrm{a}}$ & $33.22 \pm 1.96^{\mathrm{a}}$ & $40.46 \pm 8.46^{\mathrm{ab}}$ \\
& 50 & $95.6^{\mathrm{a}}$ & $12.37 \pm 0.10^{\mathrm{b}}$ & $0.70 \pm 0.03^{\mathrm{b}}$ & $1.60 \pm 0.05^{\mathrm{a}}$ & $31.13 \pm 0.05^{\mathrm{a}}$ & $38.24 \pm 3.62^{\mathrm{a}}$ \\
& 56 & $100^{\mathrm{a}}$ & $12.56 \pm 0.17^{\mathrm{b}}$ & $0.83 \pm 0.01^{\mathrm{c}}$ & $1.66 \pm 0.03^{\mathrm{a}}$ & $31.55 \pm 1.57^{\mathrm{a}}$ & $47.67 \pm 7.96^{\mathrm{b}}$ \\
Lipid & 6 & $96.7 \times$ & $12.41 \pm 0.24 \times$ & $0.71 \pm 0.01 \times$ & $1.61 \pm 0.03 \times$ & $31.25 \pm 0.34 \times$ & $35.62 \pm 4.81 \times$ \\
& 9 & $98.9 \times$ & $12.32 \pm 0.37 \times$ & $0.72 \pm 0.12 \times$ & $1.62 \pm 0.05 \times$ & $31.22 \pm 1.37 \times$ & $42.10 \pm 4.54 \times y$ \\
& 12 & $98.9 \times$ & $12.24 \pm 0.19 x$ & $0.75 \pm 0.11 \times$ & $1.69 \pm 0.05 \times$ & $33.44 \pm 1.85 \times$ & $48.64 \pm 7.10 \mathrm{y}$
\end{tabular}

Initial weight $=4.7 \pm 0.5 \mathrm{~g}$. Initial length $=6.9 \pm 0.3 \mathrm{~cm}$. Values in the column followed by the same latter are

not significantly different $(P>0.05)$.

Feed efficiency $(\mathrm{FE})=$ Weight gain $(\mathrm{g}) /$ Feed intake $(\mathrm{g})$

Protein efficiency ratio $(P E R)=$ Body weight gain $(g) /$ Protein intake $(g)$

Protein (lipid) retention $=100 \times$ (Final protein (lipid) content - Initial protein (lipid) content)/ Protein (lipid) intake

Since satisfying the energy needs will have the highest priority in the animal, a diet that is inadequate in energy will result in a reduced rate of growth. Moreover, the extent to which dietary protein will be used to supply amino acids for body protein synthesis or catabolised to supply energy is likely to be determined by the dietary balance of these two constituents. Thus, the balance of protein to energy in the diet is likely to be an important determinant of its growth potential. The optimum dietary protein: energy ratio (mg protein: $\mathrm{kcal}$ ) has been reported to be 111 for red tilapia (Santiago and Laron, 1991), 110 for Nile tilapia (El-Sayed and Teshima, 1992), 125 for hybrid striped bass (Nematipour et al., 1992) and 128 for juvenile Asian sea bass (Catacutan and Coloso, 1995). Although the interaction between dietary protein and lipid was significant for final weight and WG in the present experiment, there was no evidence of any protein-sparing by lipid. At a dietary lipid level of $9 \%$, increasing the level of dietary protein significantly increased WG of fish. However, at the dietary lipid level of 6 or $12 \%$, increasing the amount of dietary protein from $44 \%$ to $56 \%$ had no effect on WG. Similarly in the humpback grouper study of Rachmansyah et al. (2000), no clear protein-lipid sparing effect was observed. These results differ to the finding with malabar grouper ( $E$. malabaricus) by Shiau and Lan (1996) who found that the dietary protein content could be reduced from $50.2 \%$ to $44 \%$ without affecting the growth rate of the fish if the dietary energy content was maintained between 3400 and $3750 \mathrm{kcal} / \mathrm{kg}$. We are unaware of any other published study on the protein-energy sparing effect of grouper. The dietary protein requirement of dentex (Dentex dentex) could be reduced from $49 \%$ to $44 \%$ by increasing the concentration of dietary lipid from $12 \%$ to $17 \%$ (Tibaldi et al., 1996). Similarly with gilthead sea brearn, Vergara et al. (1996) concluded that the protein content of the diet could be decreased from $58 \%$ to $46 \%$ by increasing the lipid content from $9 \%$ to $15 \%$.

FE also improved with increasing dietary protein. This result agrees with that reported by Shiau and Lan (1996) for malabar grouper. In the present study, increasing the amount of lipid in the diet from $6 \%$ to $12 \%$ tended to improve FE when the fish were fed the low (44\%) protein diets, but no such effect was seen with the higher (50\% and $56 \%$ ) protein diets. The best FE (0.84) was observed for fish fed the diet containing $56 \%$ protein and $9 \%$ lipid. With gilthead bream fed diets containing 15\% lipid, FE was significantly improved when the protein content of the diet was increased from $47 \%$ to $51 \%$ (Santinha et al., 1999). Einen and Roem (1997) reported that the optimal dietary protein: energy ratio decreased with increasing fish size, from around $79.5 \mathrm{mg} / \mathrm{kcal}$ for Atlantic salmon (Salmo salar) weighing between 1 and $2.5 \mathrm{~kg}$ to about $69.1 \mathrm{mg} / \mathrm{kcal}$ for fish weighing between 2.5 and $5 \mathrm{~kg}$.

Regardless of the dietary protein content, increasing the amount of lipid in the diet led to increased retention of lipid in the fish in the present study. This was most clearly seen for fish fed the diet, containing $44 \%$ and $54 \%$ protein. Increasing the amount of dietary protein also significantly increased lipid retention. These data indicate that even at low dietary protein, lipid is not used maximally for energy, and with no evidence of any protein-sparing effect of lipid

\section{CONCLUSION}

The results of the present study indicate that a diet containing $56 \%$ protein and $9 \%$ lipid, and with a 
protein: energy ratio of $118 \mathrm{mg} / \mathrm{kcal}$ is optimal for juvenile humpback grouper.

\section{ACKNOWLEDGEMENTS}

The authors thank Dr. Kevin Williams of the CSIRO Marine Research for reviewing the manuscript. The authors also acknowledge the financial support provided by the Australian Centre for International Agricultural Research (ACIAR Project FIS/97/73) in carrying out this work.

\section{REFERENCES}

AOAC (Association of Official Analytical Chemists). 1990. Official methods of analysis, 12th Edition. Association of Official Analytical Chemists, Washington, D.C. $1141 \mathrm{pp}$

Catacutan, M.R. and R.M. Coloso. 1995. Effect of dietary protein to energy ratios on growth, survival, and body composition of juvenile Asian seabass, Lates calcarifer. Aquaculture, 131: 125--133

Chen, H.Y. and J.C. Tsai. 1994. Optimum dietary protein level for growth of juvenile grouper, Epinephelus malabaricus, fed semipurified diets. Aquaculture, 119: 265--271.

Chen, X., L. Lin, H. and Hong. 1995. Optimum content of protein in artificial diet for Epinephelus akaara. J. Oceanogr. 14: 407--412.

Einen, O and A.J Roem. 1997. Dietary protein/energy ratios for Atlantic salmon in relation fish size, growth, feed utilization, and slaughter quality. Aquaculture Nutrition. 3: 115--126.

Ellis, S., G. Viala and W. O. Watanabe. 1996. Growth and feed utilization of hatchery-reared juveniles nassau grouper fed four practical diets. Prog. Fish. Cult. 58: $167--172$.

El-Sayed, A.M. and S. Teshima. 1992. Protein and energy requirements of Nile tilapia, Oreochromis niloticus fry. Aquaculture, 103: 55--63.

Giri, N.A., K. Suwirya and M. Marzuqi. 1999. Kebutuhan protein, lemak, dan vitamin $C$ untuk yuwana ikan kerapu tikus (Cromileptes altivelis). J. Penelitian Perikanan Indonesia. 5: 38--46. (in Indonesian, with English abstract)

Jobling, M. 1983. A short review and critique of methodology used in fish growth and nutrition studies. J. Fish Biol. 23: 685--703.
Nematipour, G.R., M.L. Brown and D.M. Gatlin. 1992 Effect of dietary energy/protein ratio on growth characteristics and body composition of hybrid striped bass, Morone chrysops x M. saxatilis. Aquaculture, 107 359--368

Rachmansyah, A. Laining and A.G. Mangawe. 2000. Pengaruh rasio protein lemak yang berbeda terhadap pertumbuhan ikan kerapu bebek (Cromileptes altivelis). In: Suparno, J. Widodo, A. Sudradjat, A. Poernomo, E.S. Heruwati, K. Sumantadinata (Eds.). Prosiding Seminar Hasil Penelitian Perikanan 1999/ 2000, 21--22 September 2000, Jakarta, Indonesia. Pusat Penetian dan Pengembangan Perikanan, $p$. 221--225. (in Indonesian, with English abstract).

Santiago, C. and M. Laron. 1991. Growth response and carcass composition of red tilapia fry fed diets with varying protein and protein to energy ratios. In: S.S De Silva (Ed.). Proceeding of the Fourth Asian Fish Nutrition Workshop, Special Publication, Asian Fisheries Society, Philippines. p. 55--62.

Santinha, P.J.M., F. Madale, G. Corrase and E.F.S. Gomes. 1999. Effects of dietary protein : lipid ratio on growth and nutrient utilization in gilthead sea bream (Sparus aurata L.). Aquaculture Nutrition. 5: 147--156

Shiau, S.Y. and C.W. Lan. 1996. Optimum dietary protein level and energy ratio for growth of grouper (Epinephelus malabaricus). Aquaculture, 145: 259$-266$.

Steel, R.G.D. and J.H. Torrie. 1980. Principles and Procedures of Statistics. McGraw Hill, New York. 481 pp.

Sugama, K., Tridjoko, B. Slamet, S. Ismi, E. Setiadi and S. Kawahara. 2001. Manual for the Seed Production of Humpback Grouper, Cromileptes altivelis. Gondol Research Institute for Mariculture and Japan International Cooperation Agency. Bali. 37 pp.

Teng, S.K., T.E. Chua and P.E. Lim. 1978. Preliminary observation on the dietary protein requirement of estuary grouper, Epinephelus salmoides Maxwell, cultured in floating net-cages. Aquaculture, 15: 257--271.

Tibaldi, E., P. Beraldo, L.A.. Volpelli and M. Pinosa. 1996. Growth response of juvenile dentex (Dentex dentex) to varying protein level and protein to lipid ratio in practical diets. Aquaculture, 139: 91--99.

Vergara, J.M., L. Robaina, M. de Izqueirdo and M. la Higuer. 1996. Protein sparing effect of lipid in diets for fingerlings of gilthead sea bream. Fisheries Science, 62: 624--628. 
